УДК 347.4

DOI https://doi.org/10.32849/2663-5313/2019.11.09

\title{
Tapac Рим,
}

канд. юрид. наук,

суддя Господарського суду Львівської області

\section{ОСОБЛИВОСТІ ЗДІЙСНЕННЯ КОРПОРАТИВНИХ ПРАВ У СФЕРІ БУДІВНИЦТВА}

Стаття присвячена аналізу особливостей здійснення корпоративних прав у сфері будівництва.

3'ясовано, що можна розмежувати первинне та вторинне корпоративне інвестування. Первинне корпоративне інвестування потрібно розглядати як вкладення капіталів (иінностей) в об'єкти інвестування. Вторинне право набуття в корпоративних правовідносинах грунтується на праві учасника господарських товариств здійснити відчуження майна у статутному (складеному) капіталі товариства, що становить иінні папери, що засвідчують участь у товаристві в порядку, встановленому законодавством.

Залежно від організачійно-правової форми корпорачї ї̈ засновники можуть визначати напрями господарської діяльності, приймати рішення щодо укладення договорів, які опосередковують господарську діяльність. Таким чином, володіючи корпоративним правом участі в статутному (складеному) капіталі корпорачії, інвестор може ухвалювати рішення розпорядчого характеру в інвестииійному прочесі.

Визначено, що об'єктом корпоративного інвестування можуть бути безпосереднво основні фонди та виробничі потужності в будівельній сфері. Корпоративне інвестування має опосередкований характер. Інвестори, використовуючи корпоративну форму інвестування, вкладають кошти в статутний (складений) капітал корпоративних структур або корпоративні інвестиційні фонди. І лише наступним етапом буде вкладення інвестованих коштів безпосередньо в об'єкти будівниитва.

3'ясовано, що корпоративне інвестування може здійснюватися шляхом безпосереднього вкладення коштів в об'єкти інвестииійної діяльності або опосередковано через корпоративні інвестииійні фонди та формування складеного капіталу корпоративних структур. Зроблено висновок, що особливість корпоративного інвестування в будівельній сфері зумовлюється тим, що об'єктами інвестииійної діяльності в кінцевому результаті є основні фонди і виробничі потужності, які вводяться в експлуатаиію.

Встановлено, що розрізняють дві форми корпоративної інвестииійної діяльності в будівництві. Перша форма - ие створення корпоративних структур, шо займаються діяльністю в сфері будівниитва, шляхом набуття корпоративних прав на частку в статутному (складеному) капіталі такої юридичної особи. Іншим способом є передача корпоративних прав для використання в інвестииійній сфері будівництва.

Ключові слова: корпоративні права, корпоративне інвестування, об’єкт корпоративного інвестування, форма корпоративного інвестування.

Постановка проблеми. Розвиток юридичної науки, науково-технічний прогрес у сфері будівництва, а також усвідомлення ключового значення конкурентних механізмів як запоруки зростання економіки держави зумовлюють постійний пошук нових або удосконалення наявних форм та видів інвестування. Неабияку вагу має реалізація інвесторами власних корпоративних прав з метою здійснення інвестицій у будівництво.

До найновіших наукових праць з указаної проблеми належать роботи таких авторів, як О.М. Вінник, О.П. Сущ, У.В. Цікало, Р.Б. Шишка, Ю.М. Жорнокуй.
Метою цієї статті $€$ аналіз здійснення інвесторами корпоративних прав у інвестиційній сфері будівництва, проведення розмежування між первинним i вторинним корпоративним інвестуванням, визначення об'єкта корпоративного інвестування, а також його особливостей, виявлення форм корпоративної інвестиційної діяльності.

Виклад основного матеріалу. Корпоративне законодавство сьогодні становить важливу частину нормативного регулювання інвестиційних відносин. Однак проблема полягає у трансформації положень корпоративних норм у складовий елемент механізму 
правового регулювання будівельної галузі. Основу корпоративних відносин становить комплекс правових норм, які регулюють створення корпоративних структур, порядок управління ними, майнові та організаційні права суб'єктів корпоративних відносин, визначають форми їх передачі іншим особам. Нормативну базу корпоративного регулювання можна використовувати в інвестиційній діяльності в будівництві.

Отже, корпоративне законодавство має регуляторний вплив на відносини в будівництві. Водночас необхідно враховувати складну систему договірних зв'язків у будівництві та різний правовий статус учасників інвестиційного процесу в будівельній сфері.

Загалом корпоративне законодавство України у сфері інвестиційної діяльності повинно розвиватися в напрямі адаптації до стандартів Європейського Союзу. Першим нормативним актом в цьому аспекті була Угода про партнерство і співробітництво між Україною і Європейським Співтовариством та його державами-членами від 14 червня 1994 року. 18 березня 2004 року було ухвалено Закон України «Про загальнодержавну програму адаптації законодавства України до законодавства Європейського Союзу» [1]. Названим актом передбачено також гармонізацію корпоративного законодавства з правом СС. Серед останніх документів, спрямованих на адаптацію, крім іншого, корпоративного права до положень законодавства Європейського Союзу, є Угода про асоціацію між Свропейським Союзом та Україною, що була ратифікована Верховною Радою України 16 вересня 2014 року [2]. Зазначена Угода про асоціацію між Свропейським Союзом та Україною передбачає гармонізацію корпоративного законодавства України відповідно до вимог законодавства ЄC у сфері права компаній та корпоративного управління.

Корпоративне законодавство є складовою частиною інвестиційного законодавства України, яким інвестиція трактується як цінність (закони України «Про інвестиційну діяльність», «Про режим іноземного інвестування»). Водночас інвестиція розглядається в Податковому кодексі України як господарська операція.

Первинне корпоративне інвестування потрібно розглядати як вкладення капіталів (цінностей) в об’єкти інвестування. У літературі більше уваги звертається на правові форми інвестування в корпоративні структури і формування у такий спосіб статутного (складеного) капіталу. Це стало основою розуміння класичної моделі інвестиційної діяльності, яка розуміється як залу- чення господарських коштів (фінансових, речових) у господарську діяльність, а конкретно - в активи (власність, інші майнові права, зокрема частки та акції), метою яких $€$ збільшення майна власника шляхом зростання вартості цих активів або ж отримання частини прибутку від діяльності [3, с. 13]. 3 огляду на це інвестори, як правило, не беруть участі в поточному управлінні, а лише можуть здійснювати контроль над корпорацією. Таким чином, створюючи майнову основу діяльності корпорації, інвестори не завжди мають ефективні правові засоби впливу на результати господарської діяльності створюваних ними корпоративних структур. Це відбувається також і у будівельній сфері.

Можна виокремити договори про створення корпоративних структур (засновницький договір) як первинну підставу виникнення, зміни або припинення корпоративних прав та обов'язків. Правова форма договору може використовуватися не лише під час початкового створення корпорацій, але й у разі їх реорганізації.

Вторинне право набуття в корпоративних правовідносинах грунтується на праві учасника господарських товариств здійснити відчуження майна у статутному (складеному) капіталі товариства, що становить цінні папери, що засвідчують участь у товаристві в порядку, встановленому законодавством. Розпорядження частками у статутному (складеному) капіталі товариства та цінними паперами (акціями) учасники товариства здійснюють у правових договірних формах. Отже, $з$ настанням юридичних фактів або юридичного складу виникають, змінюються або припиняються корпоративні правовідносини, змістом яких є корпоративні права та обов'язки [4, с. 88]. Їх обсяг може впливати на інвестиційний процес. Права та обов'язки суб'єктів корпоративних відносин впливають на оптимізацію інвестиційної діяльності.

У науковій літературі зверталася увага на те, що корпоративні відносини майнового характеру виникають лише у первісний спосіб шляхом їх початкового формування, в той час як набуття суб'єктивних корпоративних прав може відбуватися як у первісний спосіб (зокрема, у разі первісного формування корпоративного правовідношення), так і у похідний, що відбувається у разі переходу корпоративних прав у порядку правонаступництва.

При цьому корпоративні відносини між засновниками юридичної особи виникають на підставі домовленості щодо її створення, що оформляється спільним рішенням про заснування юридичної особи, в результаті 
чого у відповідних суб'єктів цивільного права виникають взаємні права та обов'язки 3 досягнення відповідної мети. Майнові корпоративні відносини між засновниками (учасниками) та юридичною особою виникають 3 моменту внесення засновником в повному обсязі вкладу до статутного капіталу юридичної особи, а у разі створення акціонерного товариства - 3 моменту завершення процедури емісії акцій [5, с. 11]. Це має значення для корпоративних відносин під час інвестування будівельної сфери.

Вплив інвестора у сфері будівництва при первинному інвестуванні в корпоративну структуру обмежується вибором іï організаційно-правової структури, тому засновники (інвестори) доволі опосередковано можуть впливати на об'єкти і форми інвестування.

Залежно від організаційно-правової форми корпорації іiі засновники можуть визначати напрями господарської діяльності, приймати рішення щодо укладення договорів, які опосередковують господарську діяльність. Таким чином, володіючи корпоративним правом участі в статутному (складеному) капіталі корпорації, інвестор може ухвалювати рішення розпорядчого характеру в інвестиційному процесі.

При цьому потрібно мати на увазі, що обсяг корпоративних прав залежить від розміру частки учасника (в нашому випадку й інвестора) в складеному капіталі корпорації, тому, ухвалюючи рішення, найвищий орган корпоративної структури бере до уваги розмір часток кожного засновника (учасника). Але це не означає, що права та інтереси окремих інвесторів можуть бути порушені. Вони можуть вимагати захисту своїх інтересів у порядку, передбаченому корпоративним законодавством.

Корпоративні форми інвестування в будівництві можуть проявлятися по-різному. При первинному корпоративному інвестуванні кошти спрямовуються в статутний (складений) капітал корпорації безпосередньо або шляхом придбання цінних паперів, наприклад, акціонерного товариства. При вторинному інвестуванні інвестори можуть придбати акції, інші цінні папери на фондовому ринку або за цивільними договорами відповідно до статутних документів корпоративних юридичних осіб.

Деталізований аналіз розглядуваних відносин надав можливість дійти висновку, що важливою умовою фінансування будівельної діяльності є формування капіталу на основі диверсифікації джерел фінансування, механізмів залучення вільних коштів підприємств і заощаджень населення, створення системи інституційних інвесторів, активізації фінансових ринків у регіонах [6, с. 7] Важливе місце в перерахованих заходах відводиться також корпоративному інвестуванню, за допомогою якого можна акумулювати кошти інституційних інвесторів.

Аналіз корпоративного інвестування у будівництві зумовлює необхідність визначення об'єкта. Об'єктом корпоративного інвестування у широкому розумінні є матеріальні та нематеріальні блага, які становлять інтерес для інвесторів, корпоративного фонду та компанії з управління активами корпоративного фонду. Об'єктом корпоративного інвестування у вузькому значенні залежно від суб'єктного складу для інвесторів є права, посвідчені акціями корпоративного інвестиційного фонду, для корпоративного інвестиційного фонду - майно, передане інвесторами, а для компанії з управління активами - прибуток від подальшого розміщення грошових коштів у цінних паперах інших емітентів, корпоративні права та нерухомість або отримання різниці між купівлею/продажем акцій. Об'єкт корпоративного інвестування може бути юридичним та фактичним. Юридичним об'єктом є запис у відповідному реєстрі власників цінних паперів, який визначає об'єм прав власників цінних паперів. Фактичним об'єктом корпоративного інвестування є цінні папери, а також майно [7, с. 12].

Фактичним об'єктом корпоративного інвестування має бути будівельна нерухомість. Об'єкти будівництва є кінцевою метою корпоративного інвестування в цій сфері.

Об'єктами інвестування визнаються об'єкти господарського та інших видів суспільної діяльності, в які вкладаються інвестиції. Ними можуть бути будівлі, споруди (основні фонди), статутний (складений) капітал, устаткування, обладнання, технології, об'єкти соціальної сфери (будівництво лікарень, дитячих садків, пансіонатів для людей похилого віку), культури (реставрація пам'ятників культури), довкілля. Згідно із загальним правилом інвестування може здійснюватися у будь-які об'єкти, щодо яких законом не встановлено заборони чи обмеження [8, с. 20].

Отже, об'єктами корпоративного інвестування можуть бути безпосередньо основні фонди та виробничі потужності в будівельній сфері. Корпоративне інвестування має опосередкований характер. Інвестори, використовуючи корпоративну форму інвестування, вкладають кошти в статутний (складений) капітал корпоративних структур або корпоративні інвестиційні фонди. I лише наступним етапом буде вкладення інвесто- 
ваних коштів безпосередньо в об'єкти будівництва. При цьому існують певні обмеження, встановлені законодавством щодо певних форм корпоративного інвестування.

Форми здійснення інвестування не можна ототожнювати 3 видами інвестицій. У процесі корпоратизації окремих підприємств внеском до статутного капіталу могли бути об'єкти будівництва, в тому числі незавершеного будівництва. На момент корпоратизації державних та комунальних підприємств зазначені об'єкти повинні бути на балансі юридичної особи, а їхній правовий режим має визначатися правом повного господарського відання.

Корпоративне інвестування може здійснюватися шляхом первинного безпосереднього вкладення коштів в об'єкти інвестиційної діяльності або опосередковано через корпоративні інвестиційні фонди та формування складеного капіталу корпоративних структур. Особливість корпоративного інвестування в будівельній сфері зумовлюється тим, що об'єктами інвестиційної діяльності в кінцевому результаті є основні фонди і виробничі потужності, які вводяться в експлуатацію.

Це пов'язано з певним інтересом, спрямованим на інвестування коштів в об'єкти будівництва, адже інтерес зумовлюе відповідні дії, спрямовані на реалізацію корпоративних прав, які мають на меті спорудження (капітальний ремонт) безпосередньо чи опосередковано об'єктів будівництва.

Здійснення чи нездійснення можливості, яка становить зміст суб'єктивного корпоративного права, цілком залежить від волевиявлення самого суб'єкта корпоративних відносин. Природно, що можлива поведінка перетворюватиметься на реально здійснювану лише тоді, коли вона сприятиме задоволенню тих або інших потреб суб'єкта, тобто певна поведінка відповідатиме його інтересам. Якщо в учасника відносин немає інтересу до реалізації належного йому права, він може відмовитися від здійснення передбачених законом дій, а також він має право за власним бажанням здійснити дозволені дії в повному обсязі чи навіть частково в порядку, найбільш вигідному для задоволення власного інтересу [9, с. 112].

Поєднання корпоративних прав 3 інтересом, скерованим на введення в дію основних фондів та виробничих потужностей в будівництві, зумовлює особливості правових форм корпоративного інвестування в будівельній сфері.

Корпоративні відносини мають організаційну та майнову складові частини. У інвестиційному процесі вони поєднуються. Кор- поративні права в інвестиційній діяльності посідають важливе місце серед видів та форм інвестування. Інвестування в будівельній сфері має специфічний об'єкт, яким є спорудження і введення в експлуатацію основних фондів та виробничих потужностей, капітальний ремонт або реконструкція наявних.

Розрізняють дві форми корпоративної інвестиційної діяльності в будівництві. Перша форма - це створення корпоративних структур, що займаються діяльністю в сфері будівництва, шляхом набуття корпоративних прав на частку в статутному (складеному) капіталі такої юридичної особи. Іншим способом $є$ передача корпоративних прав для використання в інвестиційній сфері будівництва.

Будівельна сфера є галуззю інвестиційної діяльності. Ключовим залишається питання вкладення інвестицій в об'єкти будівництва. Можна розрізнити безпосереднє вкладення інвестиційного капіталу в об'єкти будівництва i опосередковане інвестування будівельної сфери.

Корпоративне інвестування в будівництві поєднує засади правового регулювання корпоративних відносин та положення, які регламентують порядок здійснення будівельної інвестиційної політики. Останні зводяться переважно до публічних приписів, що стосуються надання відповідних дозволів і погодження технічних умов та регулювання приватних відносин, які опосередковують договори підрядного типу та правовий статус суб'єкта корпоративних прав.

Інвестиційні права суб'єктів корпоративних відносин забезпечуються шляхом їхньої участі в управлінні корпоративною структурою. Для цього суб'єкти корпоративних відносин наділяються, крім майнових, немайновими (організаційними) повноваженнями.

Здійснення корпоративних прав у будівництві повинно реалізовуватися з дотриманням положень законодавства, що регулює корпоративні відносини. Рішенням власників корпоративних прав визначаються напрями іх реалізації та інвестиційна політика щодо вибору конкретних об'єктів будівництва.

При цьому здійснення корпоративних прав проводиться з урахуванням дозвільних та обмежувальних публічних норм у сфері будівництва, тому прийняття корпоративного рішення повинно відповідати загальним нормам цивільного права та спеціальним положенням, які регулюють відносини в будівництві. Це має значення для вибору та здійснення діяльності в будівельній сфері у формі корпоративного інвестування. 


\section{Висновки}

За наслідками проведеного дослідження можна дійти певних висновків.

По-перше, можна виділити первинні i вторинні форми корпоративного інвестування. Під час первинного інвестування відбувається створення корпоративної структури шляхом реалізації домовленості інвесторів та формування ними статутного капіталу. Вторинне характеризується набуттям корпоративних прав наявних суб'єктів підприємництва. При цьому необхідно звернути увагу на відносну неефективність впливу інвесторів (учасників, акціонерів) на результати господарської діяльності, адже їхня участь обмежується контролем над діяльністю створеної ними юридичної особи, вони не здійснюють поточного управління.

По-друге, об'єктами корпоративного інвестування можуть бути безпосередньо основні фонди та виробничі потужності в будівельній сфері. Корпоративне інвестування має опосередкований характер. Інвестори, використовуючи корпоративну форму інвестування, вкладають кошти в статутний (складений) капітал корпоративних структур або корпоративні інвестиційні фонди. I лише наступним етапом буде вкладення інвестованих коштів безпосередньо в об'єкти будівництва.

По-третє, розрізняють дві форми корпоративної інвестиційної діяльності в будівництві. Перша форма - це створення корпоративних структур, що займаються діяльністю в сфері будівництва, шляхом набуття корпоративних прав на частку в статутному (складеному) капіталі такої юридичної особи. Іншою формою $є$ передача корпоративних прав для використання в інвестиційній сфері будівництва. Можна розрізнити без- посереднє вкладення інвестиційного капіталу в об'єкти будівництва і опосередковане інвестування будівельної сфери.

\section{Список використаних джерел:}

1. Про загальнодержавну програму адаптації законодавства України до законодавства Європейського Союзу : Закон України від 18.03.2004 p. № 1629-IV / Верховна Рада Украӥни. Відомості Верховної Ради України. 2004. № 29. Ст. 367.

2. Про ратифікацію Угоди про асоціацію між Україною, з однієї сторони, та Європейським Союзом, Європейським співтовариством з атомної енергії і їхніми державами-членами, з іншої сторони : Закон України від 16.09.2014 p № 1678-VII / Верховна Рада Украӥни. Відомост Верховної Ради України. 2014. № 40. Ст. 2021.

3. Michalak A. Finansowanie inwestycji w teorii i praktyce. Warszawa, 2007. s. 13.

4. Луць В.В. Про механізм правового регулювання корпоративних відносин. Актуальні проблеми приватного права: матеріали XVII науковопракт. конф., присв. 97 річниці з дня народж. докт. юрид. наук, проф. В.П. Маслова. Харків : Право, 2019. С. 85-89.

5. Яроцька М.В. Юридичний склад як підстава виникнення майнових цивільних правовідносин : автореф. дис. ... канд. юрид. наук : 12.00.03. Київ, 2018. 16 с

6. Ціленко В.А. Господарсько-правове забезпечення державної будівельної політики : автореф. дис. ... канд. юрид. наук : 12.00.04. Київ, 2018. $20 \mathrm{c}$.

7. Сущ О.П. Правове регулювання корпоративного інвестування: цивільно-правовий аспект автореф. дис. ... канд. юрид. наук : 12.00.03. Київ, 2014. $20 \mathrm{c}$

8. Вінник О.М. Інвестиційне право : навчальний посібник. Київ : Юридична думка, 2005. 568 с.

9. Здійснення та захист корпоративних прав в Україні / за ред. проф. В.В. Луця : монографія. Тернопіль, 2007. 320 с.

The article is devoted to the analysis of peculiarities of the exercise of corporate rights in the field of construction.

It is found out that it is possible to distinguish primary and secondary corporate investing. Initial corporate investment should be considered as an investment of capital (values) in the objects of investment. The secondary right of acquisition in corporate legal relations is based on the right of the participant of business companies to alienate property in the statutory (compounded) capital of the company, securities that certify participation in the company in the order established by law.

Depending on the organizational and legal form of the corporation, its founders may determine the directions of economic activity, make decisions on the conclusion of contracts that mediate economic activity. Thus, having a corporate right to participate in the statutory (compounded) capital of the corporation, the investor can make decisions of an administrative character in the investment process.

It is determined that directly fixed assets and production facilities can be the objects of corporate investment in the construction sphere. Corporate investment is indirect. Investors, using the corporate form of investing, invest in the statutory (compound) capital of corporate structures or corporate investment funds. And only the next stage will be the investment of the funds directly into the object of construction.

It has been found out that corporate investment can be carried out by initial direct investment in the objects of investment activity or indirectly through corporate investment funds and the formation of compound 
capital of corporate structures. It is concluded that the peculiarity of corporate investment in the construction sector is the fact that the objects of investment activity, in the end, are fixed assets and production facilities that are put into operation.

It is established that there are two forms of corporate investment activity in construction. This is the formation of corporate structures engaged in construction activities by acquiring corporate rights to a share in the statutory (compound) capital of such a legal entity. Another way is to transfer corporate rights for use in construction investment.

Key words: corporate rights, corporate investing, object of corporate investing, form of corporate investing. 